FIDEL BETWEEN THE LINES 
FIDEL 
LAURA-ZOË HUMPHREYS

\title{
BETWEEN THE LINES
}

\author{
PARANOIA AND AMBIVALENCE
}

IN LATE SOCIALIST CUBAN CINEMA 
(C) 2019 Duke University Press

All rights reserved

Printed in the United States of America on acid-free paper $\infty$

Cover designed by Matthew Tauch

Text designed by Aimee C. Harrison

Typeset in Minion Pro, Franklin Gothic, and Serifa Std

by Westchester Publishing Services

Library of Congress Cataloging-in-Publication Data

Names: Humphreys, Laura-Zoe, [date] author.

Title: Fidel between the lines : paranoia and ambivalence in late socialist

Cuban cinema / Laura-Zoe Humphreys.

Description: Durham : Duke University Press, 2019. | Includes

bibliographical references and index.

Identifiers: LCCN 2019006366 (print)

LCCN 2019012785 (ebook)

ISBN 9781478007142 (ebook)

ISBN 9781478005476 (hardcover : alk. paper)

ISBN 9781478006244 (pbk. : alk. paper)

Subjects: LCSH: Motion pictures-Cuba-History and criticism. | Motion pictures-Political aspects-Cuba. | Motion pictures-Cuba-History2oth century. | Motion pictures-Cuba-History-21st century.

Classification: LCC PN1993.5.C8 (ebook) | LCC PN1993.5.C8 H867 2019

(print) | DDC 791.43097291-dc23

LC record available at https://lccn.loc.gov/2019006366

Cover art: View of the Monument to the Victims of the uss Maine,

Havana, Cuba. Illustration by Matthew Tauch.

Duke University Press gratefully acknowledges Tulane University's School of Liberal Arts, which provided funds toward the publication of this book. 